\title{
El estallido de la controversia arriana*
}

\author{
GonZALO FERNÁNDEZ ${ }^{* *}$
}

\section{RESUMEN}

Este artículo estudia el inicio de la disputa arriana. Fuentes: Epifanio de Salamina, Eusebio de Cesarea, Basilio de Cesarea, Filoslorgio, Rufino de Aquileya, Sócrates, Procopio de Cesarea, Sozomeno, Atanasio de Alejandría y Teodoreto de Ciro.

\section{SUMMARY}

This article deals with the beginning of arian dispute. Sources: Epiphanius of Salamis, Eusebius of Caesarea, Basil of Caesarea, Philostorgius, Rufinus of Aquileia, Socrates, Procopius of Caesarea, Sozomen, Athanasius of Alexandria and Theodoret of Cyr.

La querella arriana se inicia en torno a 318. Epifanio de Salamina (Panar. Haer., 69, 2) afirma en la iglesia alejandrina de «Bukolia», regentada por Arrio desde el año 313, este personaje reúne a siete presbíteros, doce diáconos y setecientas vírgenes consagradas con vistas a explicar las Sagradas Escrituras. El de Salamina añade que en este tiempo el obispo libio Segundo de Ptolemaida participa ya de las ideas de Arrio ${ }^{1}$.

* Este trabajo se ha beneficiado parcialmente de una subvención de la DGICYT (PB 0186/94).

** Universidad de Valencia.

1 Es EPIFANIO de Salamina, Panar. Haer, 68, 4 y 71,1 quien afirma el gobierno de la iglesia alejandrina de «Bukolia» por parte de Arrio. Por lo que se refiere a la topografía cristiana de Alejandría a principios del siglo IV vid. H. LECLERCO, s.v. “Alexandrie», DACL, 1, 1907, col. 1.107. 
Las setecientas vírgenes de Epifanio constituyen un testimonio sospechoso a causa de su desmesura. Puede referirse a la presencia de discípulas de Arrio. Éste es un fenómeno muy común en el cristianismo primitivo que influye en algunos antecesores del presbítero de «Bukolia» como Orígenes o Luciano de Antioquía ${ }^{2}$. Otro motivo que avala la exageración de tal guarismo estriba en que el concilio de Alejandría, reunido hacia 320 , sólo sanciona a Arrio, seis presbíteros y seis diáconos de dicha ciudad (Sócrates, Hist. Eccl., I, 6) bien que tales castigos se completen poco después con la pena impuesta a dos presbíteros y cuatro diáconos de Mareotis ${ }^{3}$.

La cita del obispo Segundo de Ptolemaida por Epifanio de Salamina (loc. cit.) tiene gran interés. Señala la difusión de las teorías de Arrio entre el episcopado libio. Ello se explica por el miedo de aquellos obispos al arraigo del sabelianismo en la zona. En cambio, no parece acertada la hipótesis de $O$. Seeck que la achaca a una amistad de Segundo de Ptolemaida con Arrio al ser libios los dos ${ }^{4}$. El testimonio de Epifanio se completa con el aportado por Sócrates (loc. cit.) quien menciona la deposición de dos obispos de aquella región (Segundo de Ptolemaida y Teonas de Marmárica) por los sinodales alejandrinos.

La susodicha noticia de Epifanio se vincula también con un informe del historiador anomeo Filostorgio que se conoce a través de Nicetas Coniata ${ }^{5}$. Allí Filostorgio proporciona una lista de obispos partidarios de Arrio. En Libia Superior cita a Segundo de Ptolemaida, Teonas de Marmárica, Dacio de Berenice, Segundo de Teuquera, Zapiro de Barca y Sentiano de Boreión. Este último gobierna una sede de menos importancia en base a dos causas: la ausencia de sus titulares en el sínodo de Nicea de 325; y el exiguo número de cristianos que en época de Justiniano residen en Boreion frente a la mayoría de habitantes judíos (Procopio de Cesarea, De aedif. VI, 2, 14).

2 Vid. los ejemplos aludidos por J. M. BLÁZQUEZ, «Prisciliano, introductor del ascetismo en Hispania. Las fuentes. Estudio de la investigación moderna”, Actas del I Concilio Caesaraugustano, Zaragoza, 1980, pág. 75.

3 Vid. E. Schwartz, Zur Geschichte des Athanasius, Gesammelte Schriften, 3, Berlín, 1959, pág. 73 .

4 Vid. O. SEEck, Geschichte der Untergans des antiken Welt, vol. III, Darmstadt, 1964 (reimpr.), pág. 401.

5 Vid. Nicetas Coniata, Thesaurus, V, 7, P.G. 139, col. 1.368. El presente testimonio figura asimismo en J. BIDEZ, Philostorgius Kirchengeschichte, Berlín, 1913, pág. 9. 
La segunda noticia sobre el origen de la disputa arriana corresponde al mismo Epifanio de Salamina (Panar. Haer., 69, 3). Esta fuente dice que Melecio de Licópolis acusa a Arrio ante Alejandro de Alejandría en virtud de la peligrosidad de las doctrinas profesadas y expuestas por el presbítero de la iglesia de «Bukolia». El obispo de Licópolis se convierte así en el portavoz de las dos tendencias monarquianas que se desenvuelven en la cristiandad egipcia: los aborígenes del País del Nilo refractarios a los influjos de la cultura helénica; y los monarquianos alejandrinos, herederos de aquellos correligionarios suyos que en 257 acusan a Dionisio de Alejandría ante su homónimo de Roma por sostener que el Hijo es una criatura extraña (cuando no desigual) a la esencia del Padre (Atanasio de Alejandría, De sent. Dion., 4; Eusebio de Cesarea, Hist. Eccl., VIII, 26, y Basilio de Cesarea, Ep., 9, 2.

Los monarquianos alejandrinos poseen una civilización, idioma y modo de vida griegos mas ello no impide su hostilidad a la «Logostheologie». En las postrimerías de la década de 310 a 320 ambas corrientes monarquianas se hallan unidas bajo la égida de Melecio de Licópolis, pues su temor y enemiga a la teología de Arrio (el corifeo más activo de la «Teología del Logos") les permite superar las graves diferencias derivadas de su aceptación o rechazo del espíritu de la Hélade. Pero en los años iniciales del decenio siguiente los dos grupos se separan por el distinto nivel de su cultura que es lo bastante hondo para impedir la prosecución de una alianza al fin y al cabo episódica. En el seno de este alejamiento los monarquianos alejandrinos ocasionan la génesis del cisma de Coluto dentro de la cristiandad de aquella urbe. Los oriundos de Egipto siguen leales a Melecio de Licópolis y desarrollan el problema meleciano en la iglesia egipcia con ciertas ramificaciones en Abisinia.

Sozomeno (Hist. Eccl., I, 15) y Rufino de Aquileya (Hist. Eccl., I, 1) manifiestan que Alejandro de Alejandría difiere tomar una decisión ante el orto de la crisis arriana. Esto se aclara por la naturaleza de origenista moderado que ofrece Alejandro. Ese carácter le induce a no identificarse ni con el origenismo radical de Arrio ni con el monarquianismo de sus oponentes. Aquellas dudas del obispo esclarecen, a su vez, la aparición del cisma coluciano en Alejandría. Sus protagonistas son los monarquianos de dicha ciudad seguidores de la cultura helénica pero adversarios del origenismo. La tardanza de Alejandro en proceder contra Arrio y la urgencia de atender a sus simpatizantes impulsan a su jefe, el presbítero Coluto, a efectuar ordenaciones sacerdotales consideradas ilegítimas por Alejandro. Esto esclarece el cargo que Atanasio (Apol. c. arian., 74-75) 
hace a Coluto de ejercer funciones episcopales pese a no ser más que un presbítero.

Dada la amenaza que el cisma coluciano entraña para la diócesis de Alejandría, Alejandro se decide por fin a adoptar una postura antiarriana y ordena la retirada de sus proposiciones al presbítero de «Bukolia». Sozomeno (Hist. Eccl., I, 15) afirma que el obispo insta a Arrio a defender

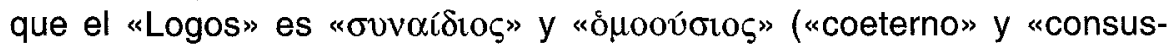
tancial») con el Padre. De esta fuente sólo puede admitirse que Alejandro exige a Arrio una afirmación de la primera cualidad del Hijo (es decir que

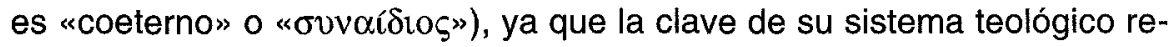
side en su creencia en la generación «ab aeterno» del "Logos». Por el contrario es impensable que Alejandro requiera de Arrio una confesión de la consustancialidad del Hijo al nunca emplear el término «ó $\mu \circ 0 u ́ \sigma i o \zeta »$ («consustancial») en sus escritos.

De otra parte Alejandro es seguidor de Orígenes bien que en un sentido moderado. Los origenistas de la generación anterior habian condenado

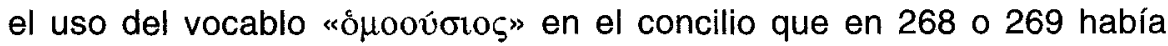
condenado a Pablo de Samosata, obispo a la sazón de Antioquía. Teniendo en cuenta la existencia de Alejandría de una comunidad monarquiana encabezada por Coluto, es impensable la aceptación del vocablo «ójoov́otoc» por el obispo Alejandro, pues hubiese renegado en ese caso de su ideología origenista. Además, otorgando validez al susodicho concepto, Alejandro habría roto la postura equidistante de Arrio y Coluto que parece asumir hasta el desenlace del sínodo alejandrino que sanciona a Arrio y los más tempranos de sus partidarios.

Arrio rehusa someterse y Alejandro convoca la tantas veces mentada asamblea sinodal de Alejandría ${ }^{6}$. Aquí finaliza el primer capítulo de la disputa arriana, pues tras su castigo por aquellos conciliares el antiguo presbítero de «Bukolia» se refugia en Cesarea de Palestina, junto al obispo Eusebio, cuya intervención en la querella motiva que la controversia rebase sus confines primigenios de Egipto y entre en una fase nueva y más compleja.

6 Sobre el devenir y los acuerdos del sínodo alejandrino que hacia el año 320 condena a Arrio y sus primeros seguidores, vid. Alejandro De Alejandría, Ep. enclycl., en Sócrates, Hist. Eccl. I, 6. 